\title{
Role of Osteopontin in Systemic Lupus Erythematosus
}

\author{
Beata Kaleta
}

Received: 29 January 2014/ Accepted: 7 April 2014/Published online: 11 June 2014

(C) The Author(s) 2014. This article is published with open access at Springerlink.com

\begin{abstract}
Systemic lupus erythematosus (SLE) is a multisystemic disease, caused by a variety of factors, which lead to immunological abnormalities. Osteopontin (OPN) is a pleiotropic protein, important in bone remodeling and immune system signaling. OPN, produced by various cells, including immune cells, plays a key role in regulating T-helper 1/T-helper 2 balance, stimulating B lymphocytes to produce antibodies, regulating macrophages, neutrophils and inducing dendritic cells. OPN expression is influenced by genetic polymorphisms of its promoter, hormones and cytokines. Over expression of OPN has been associated with the pathogenesis of immune-mediated diseases. OPN has been implicated in the development of murine model of lupus and in humans with SLE. In this review, I will present current state of research on the role of OPN and $O P N$ gene polymorphisms in pathogenesis and clinical course of SLE. A better understanding of the role of OPN in SLE will contribute to more precise diagnosis and treatment of the disease.
\end{abstract}

Keywords Osteopontin - Systemic lupus erythematosus . Gene $\cdot$ Polymorphism

\begin{tabular}{|c|c|c|}
\hline \multicolumn{3}{|c|}{ Abbreviations } \\
\hline SLE & Systemic lupus erythematosus & \\
\hline OPN & Osteopontin & \\
\hline $\mathrm{IL}$ & Interleukin & \\
\hline SIBLING & $\begin{array}{l}\text { Small integrin-binding ligand } \\
\text { glycoprotein }\end{array}$ & N-linked \\
\hline
\end{tabular}

B. Kaleta $(\square)$

Department of Clinical Immunology, Transplantation Institute,

Medical University of Warsaw, Nowogrodzka 59,

02-006 Warsaw, Poland

e-mail: kaletabeata1@gmail.com $\begin{array}{ll}\text { DCs } & \text { Dendritic cells } \\ \text { NK } & \text { Natural killer } \\ \text { TNF } & \text { Tumor necrosis factor } \\ \text { IFN } & \text { Interferon } \\ \text { pDC } & \text { Plasmacytoid DC } \\ \text { Th } & \text { T-helper } \\ \text { SLEDAI } & \text { SLE disease activity index }\end{array}$

\section{Introduction}

Systemic lupus erythematosus (SLE) is a chronic multisystemic disease of autoimmune origin, characterized by involvement of multiple organs (skin, lungs, heart, joints, blood vessels, liver, kidneys, hematologic and nervous systems). SLE is caused by environmental, hormonal and genetic factors which lead to immunological abnormalities (Kotzin 1996; Mills 1994). Deregulation of B and T lymphocytes activation leads to production of autoantibodies and abnormalities in cytokine expression. Autoantibodies [against double-stranded DNA (ds-DNA), SS-A (anti-Ro), SS-B (anti-La), anti-Sm, anti-RNP] form complexes with antigens, which are deposited in organs, cause inflammation and tissue damage (Giles and Boackle 2013; Lindop et al. 2012; Marks and Tullus 2012; Rekvig et al. 2012). Deregulation in cytokine expression followed by inflammatory processes is also a cause of tissue injury. It was demonstrated that interleukin (IL)-6, B lymphocytes stimulators, IL-17, IL-18 and interferon (IFN)- $\alpha$ have the pathogenic role in SLE (Yap and Lai 2013).

Osteopontin (OPN), also known as early T lymphocyte activation-1 or secreted phosphoprotein 1 , is a member of the small integrin-binding ligand $\mathrm{N}$-linked glycoprotein (SIBLING) family proteins (Fisher et al. 2001; Ramaiah and Rittling 2008; Rangaswami et al. 2006). OPN for the 
first time was identified in 1986 as a major sialoprotein of bone, linking bone cells and hydroxyapatite, the main inorganic constituent of human bone tissue (Oldberg et al. 1986). OPN is produced by various cell types such as immune cells: B cells and T cells, natural killer (NK)T cells, NK cells, macrophages, neutrophils, dendritic cells (DCs), bone cells (osteoblasts and osteocytes), breast epithelial cells or neurons. OPN can be found in many organs such as bone, lung, liver, brain, joints, adipose tissue and body fluids: blood, urine, bile and semen (Denhardt and Noda 1998; Ramaiah and Rittling 2008; Uede 2011). OPN has been found to be an effective biomarker for a number of cancers (Afify et al. 2009; Ramaiah and Rittling 2008) and immune-mediated diseases, including multiple sclerosis (Carecchio and Comi 2011; Harris and Sadiq 2009; Murugaiyan et al. 2008), SLE (Kariuki et al. 2009; Kariuki and Niewold 2010; Murugaiyan et al. 2008; Zandman-Goddard and Shoenfeld 2003), rheumatoid arthritis (Cantor 1995; Gravallese 2003; Murugaiyan et al. 2008), atherosclerosis (Cho et al. 2009; Scatena et al. 2007), cardiovascular disease (Singh et al. 2007), inflammatory bowel disease (Glas et al. 2011; Mishima et al. 2007), asthma (Frenzel and Weiss 2011; Konno et al. 2011) and liver diseases (Cao et al. 2012; Ramaiah and Rittling 2008; Yilmaz 2012).

\section{OPN Gene: Structure and Polymorphism}

Human $O P N$ gene is mapped on the long arm of chromosome $4(4 q 21-4 q 25)$. It is composed of seven exons. The first exon is untranslated. Exons 2-7 contain coding sequences. $O P N$ gene promoter includes several types of regulatory sequences: the TATA box, GC box, reverse CCAAT cassette and several transcription factor-binding sequences: PEA3, E2A, AP1 and Ets (Sodek et al. 2000). Moreover, it was shown that $O P N$ gene expression is affected by a number of cytokines (e.g., IL-1 $\beta$, IL-6, tumor necrosis factor (TNF)- $\alpha$, IFN- $\gamma$ ), hormones (vitamin D, estrogen, angiotensin II, glucocorticoids), platelet-derived growth factor and oxidized low-density lipoprotein (Denhardt and Noda 1998). In addition, the expression of OPN is influenced by genetic polymorphisms of its promoter (Chiu et al. 2010; Jiang et al. 2013). OPN gene is highly polymorphic. Several polymorphisms in the human $O P N$ gene have been identified: in the $5^{\prime}$ flanking region, in exons and introns and in the $3^{\prime}$ untranslated region (Giacopelli et al. 2003; Iwasaki et al. 2001; Mochida et al. 2004).

\section{Structure, Metabolism and Function of OPN}

Osteopontin is a pleiotropic protein and its functions are linked to various physiological functions and pathological conditions. OPN interacts with cells via two binding domains. Through the adhesive RGD motif (arginine-glycine-aspartate domain), OPN interacts with $\alpha \mathrm{v} \beta 1, \alpha v \beta 3$, $\alpha v \beta 5, \alpha v \beta 6, \alpha 8 \beta 1$ and $\alpha 5 \beta 1$ integrins (Denda et al. 1998; $\mathrm{Hu}$ et al. 1995; Yokosaki et al. 2005). Moreover, OPN contains a SVVYGLR domain that mediates interactions with $\alpha 9 \beta 1, \alpha 4 \beta 1$ and $\alpha 4 \beta 7$ integrins (Green et al. 2001; Ito et al. 2009). OPN signaling via integrins modulates the phosphorylation of kinases which are involved in $\mathrm{NF}-\kappa \mathrm{B}$ activation and regulation of cytokines production (Urtasun et al. 2012). Osteopontin contains an aspartate-rich region near the C-terminal sequence. This domain is exposed as a result of proteolysis by thrombin and is able to interact with the CD44 receptors. It enables $\mathrm{T}$ cell chemotaxis and fibroblast adhesion. CD44 ligation with OPN leads to reduction in IL-10 gene expression in macrophages (Weber et al. 1996).

Osteopontin function is highly modified by post-translational modifications, including phosphorylation, O-linked glycosylation, sialylation and tyrosine sulfation. They are necessary for OPN regulation of mineralization, bone resorption and migration of cancer cells (Al-Shami et al. 2005; Gericke et al. 2005; Kazanecki et al. 2007; Razzouk et al. 2002).

OPN, secreted by osteoblasts, osteoclasts and osteocytes, is important in mineralization and bone resorption (Denhardt and Guo 1993; Denhardt and Noda 1998). Recently, this protein was found to be relevant in regulation of immunity and inflammation, angiogenesis, oncogenesis, cancer progression and apoptosis (Cantor 1995; Cao et al. 2012; Denhardt and Guo 1993; Murugaiyan et al. 2008). Due to the fact that OPN is expressed by many different cell types of the immune system, is upregulated in response to injury and inflammation and regulates immunological response, it may be classified as a cytokine (Brown 2012; Denhardt and Guo 1993; Heilmann et al. 2009; Koh et al. 2007; Wang and Denhardt 2008). Osteopontin is highly expressed by macrophages and regulates their migration, activation, capacity for phagocytosis and nitric oxide production (Ashkar et al. 2000; Brown 2012; Wang and Denhardt 2008; Weber et al. 1996). It has been demonstrated that OPN is a chemoattractant for neutrophils (Koh et al. 2007; Wang and Denhardt 2008) and induces DCs maturation. OPN promotes activation of $\mathrm{T}$ lymphocytes, and regulates the T-helper 1 (Th1)/Th2 balance. Via interaction with $\alpha \mathrm{v} \beta 3$ integrin, OPN up-regulates IL-12. Through CD44 receptor, OPN downregulates IL-10 (Ashkar et al. 2000). Recent findings revealed that non-secreted form of OPN enhances IFN- $\alpha$ expression through the IFN regulatory factor 7 activation upon Tolllike receptor (TLR)9 stimulation in plasmacytoid DCs (pDC) (Shinohara et al. 2006). Moreover, OPN activates and stimulates antibodies production by B lymphocytes 
(Ashkar et al. 2000; Iizuka et al. 1998; Lampe et al. 1991). In addition, some studies suggested that OPN enhances IL17 producing Th17 cell responses by inhibiting the production of IL-27 and IL-17 inhibitor produced by pDC (Murugaiyan et al. 2008; Shinohara et al. 2008).

\section{Role of OPN in SLE}

\section{Studies Performed in Murine Models of SLE}

OPN was reported to be highly expressed in the MLR/lpr mouse (commonly used model of the human SLE) (Iizuka et al. 1998; Lampe et al. 1991; Miyazaki et al. 2005; Weber and Cantor 2001; Wüthrich et al. 1998). In mice, CD4-/ $\mathrm{CD}^{-} \mathrm{T}$ cells expressed high levels of OPN. Overexpression of OPN in murine model of SLE induces B cell activation and $\mathrm{IgG}$ and $\operatorname{IgM}$ production, elevated autoantibodies (including anti-ds-DNA) levels and enhanced cytokine expression (TNF- $\alpha$, IFN- $\gamma$ and IL-1 $\beta$ ) (Iizuka et al. 1998; Miyazaki et al. 2005; Weber and Cantor 2001; Wüthrich et al. 1998). Overproduction of these cytokines has been shown to be involved in the pathogenesis of SLE (Yap and Lai 2013). The biological importance of OPN in IFN- $\alpha$ responses was emphasized by the finding that in the absence of OPN in mice, IFN- $\alpha$ production by $\mathrm{pDC}$ through TLR9 pathway was impaired (Shinohara et al. 2006). Moreover, it has been found that elevated circulating levels of OPN are associated with renal damage in the MLR/lpr mice (Miyazaki et al. 2005; Ophascharoensuk et al. 1999; Wüthrich et al. 1998).

\section{Studies Performed in Humans}

In the literature, there are reports suggesting that OPN participates in the pathogenesis of some autoimmune diseases (Cantor 1995; Cho et al. 2009; Denhardt and Guo 1993; Gravallese 2003; Murugaiyan et al. 2008; Ramaiah and Rittling 2008; Scatena et al. 2007; Sodek et al. 2000; Uede 2011).

In 1989, first report was published to connect OPN to immunity (Patarca et al. 1989). In 1995, Katagiri and colleagues for the first time evaluated whether elevated OPN level can be detected in patients with autoimmune diseases (Katagiri et al. 1995). These authors observed that serum OPN level is elevated in SLE and RA patients compared with healthy donors. Moreover, they described two forms of OPN: large $(64,000 \mathrm{Da})$ and small $(32,000 \mathrm{Da})$. The small form of OPN may be derived from the large since it can be cleaved by thrombin. This thrombin-cleaved OPN exposes an epitope for integrin receptors: $\alpha 4 \beta 1, \alpha 9 \beta 1$ and $\alpha 9 \beta 4$ (Green et al. 2001; Ito et al. 2009). Li et al. (1999) and Lou et al. (2006) likewise demonstrated that plasma OPN concentration is elevated in SLE patients. In another study, Wong et al. (2005) measured the plasma concentration of OPN in 54 Chinese SLE patients with (renal disease in SLE: RSLE) and without (SLE) renal impairment. They demonstrated that OPN concentrations were significantly higher in SLE and RSLE patients than in controls $(p<0.001)$ and correlated positively and significantly with SLE disease activity index (SLEDAI) ( $r=0.308, p=0.023$; Wong et al. 2005). Moreover, in RSLE patients, OPN concentration showed a positive correlation with the pro-inflammatory cytokine IL18 level $(r=0.404, p=0.037)$. This cytokine exerts a variety of effects on DCs, T lymphocytes and NK cells, and is an inducer of IFN- $\alpha$ to promote Th1 differentiation (Yap and Lai 2013). Wong et al. (2005) suggested that in combination with the inflammatory activities of IL-18, OPN can enhance the Th1-mediated inflammatory process in the exacerbation of SLE and RSLE. Similar finding was observed by Afify et al. (2009) in children with SLE (40 patients and 30 matched controls). The study showed that OPN concentrations were significantly higher in SLE patients with and without renal disease than in the controls ( $p=0.000$ and $p=0.002$, respectively). Moreover, plasma OPN level correlated positively with disease activity index in both groups $(r=0.34, p=0.04)$. In patients with renal disease, there was a positive correlation between IL-18 and OPN concentration ( $r=0.48$, $p=0.004)$. Rullo et al. (2013) hypothesized that increased circulating plasma OPN levels may be associated with organ damage in pediatric SLE $(n=42)$ and adult SLE $(n=23)$. Plasma OPN concentrations were significantly higher in both groups than in controls $(p=0.03$ and $p=0.02$, respectively). In addition, Rullo et al. (2013) showed that increased OPN is associated with higher titer of antibodies to ds-DNA ( $p=0.001)$ and elevated IFN- $\alpha$ $(p=0.02)$, which were shown to be important in pathogenesis and clinical manifestations of SLE (Bengtsson et al. 2000). Moreover, Rullo et al. (2013) showed a positive correlation between OPN and SLEDAI in six months.

These results (summarized in Table 1) suggest that the production of OPN is associated with SLE development and may serve as a potential marker of SLE activity and organ damage.

\section{Role of OPN Gene Polymorphism in SLE}

Studies Performed in Murine Models of SLE

Polymorphic OPN alleles have been implicated in the mouse model of lupus in the study of Miyazaki et al. (2005). These authors reported that OPN gene 
Table 1 Main studies about osteopontin (OPN) role in human SLE

\begin{tabular}{|c|c|c|}
\hline References & Study population & Relevant results \\
\hline $\begin{array}{l}\text { Katagiri } \\
\quad \text { et al. } \\
\quad(1995)\end{array}$ & 10 SLE patients & $\begin{array}{l}\text { Serum OPN level were elevated } \\
\text { in SLE patients but not in } \\
\text { healthy donors } \\
\text { Two forms of OPN: large and } \\
\text { small were detected. The small } \\
\text { form may be derived from the } \\
\text { large since it can be cleaved by } \\
\text { thrombin }\end{array}$ \\
\hline $\begin{array}{l}\text { Wong } \\
\text { et al. } \\
\text { (2005) }\end{array}$ & 54 SLE patients & $\begin{array}{l}\text { Plasma OPN concentrations were } \\
\text { significantly increased in SLE } \\
\text { and RSLE patients }(p<0.001) \\
\text { and the elevation correlated } \\
\text { positively with SLEDAI } \\
(r=0.308, p=0.023) \\
\text { In RSLE patients, OPN } \\
\text { concentration showed a } \\
\text { positive correlation with IL-18 } \\
\text { level }(r=0.404, p=0.037)\end{array}$ \\
\hline $\begin{array}{l}\text { Lou et al. } \\
\quad(2006)\end{array}$ & 38 SLE patients & $\begin{array}{l}\text { Plasma OPN concentrations were } \\
\text { significantly higher in SLE } \\
\text { patients than in controls } \\
(p<0.001) \text { and showed a } \\
\text { significant positive correlation } \\
\text { with SLEDAI }(r=0.93, \\
p<0.001)\end{array}$ \\
\hline $\begin{array}{c}\text { Afify et al. } \\
(2009)\end{array}$ & 40 pSLE patients & $\begin{array}{l}\text { Plasma OPN concentrations were } \\
\text { significantly higher in SLE and } \\
\text { RSLE patients than in controls } \\
(p=0.002 \text { and } p=0.000) \\
\text { and correlated positively with } \\
\text { SLEDAI ( } r=0.34, p=0.04) \\
\text { In patients with renal disease, } \\
\text { there was a positive correlation } \\
\text { between IL-18 and OPN } \\
\text { concentration }(r=0.48, \\
p=0.004)\end{array}$ \\
\hline $\begin{array}{l}\text { Rullo et al. } \\
\text { (2013) }\end{array}$ & $\begin{array}{l}42 \text { pSLE patients and } \\
23 \text { SLE adult } \\
\text { patients }\end{array}$ & $\begin{array}{l}\text { Plasma OPN concentrations were } \\
\text { significantly higher in pSLE } \\
\text { and adult SLE patients than in } \\
\text { controls }(p=0.03 \text { and } \\
p=0.02) \text { and the elevation } \\
\text { correlated positively with six- } \\
\text { month SLEDAI in both groups } \\
(r=0.51 \text { and } 0.51, p=0.001 \\
\text { and } p=0.01) \\
\text { Increased OPN at baseline was } \\
\text { associated with antibodies to } \\
\text { ds-DNA }(p=0.001) \text { and } \\
\text { elevated IFN- } \alpha(p=0.02)\end{array}$ \\
\hline
\end{tabular}

$O P N$ osteopontin, $S L E$ systemic lupus erythematosus, $p S L E$ pediatric SLE, RSLE renal disease in SLE, SLEDAI SLE disease activity index

polymorphism induces enhanced expression of immunoglobulins: IgG3, Ig2a and IgM and cytokines: IFN- $\gamma$, TNF$\alpha$, IL-1 $\beta$ which play an important role in lupus mice models and in human SLE. It was shown that type I IFN signaling pathway is essential for up-regulation of TLR7 and TLR9 receptors in B lymphocytes and activation of B lymphocytes through these receptors to produce lupusspecific autoantibodies (Thibault et al. 2008). The role of TNF- $\alpha$ in lupus mice models is controversial. In some mouse models, the deficiency of TNF- $\alpha$ provoked autoimmunity (Kontoyiannis and Kollias 2000). In contrast, $\mathrm{TNF}-\alpha$ concentration was elevated in sera and renal tissue of MLR/lpr lupus mice and the levels of this cytokine correlated with the severity of kidney disease (Yokoyama et al. 1995). Overproduction of IL-1 $\beta$ has been shown to be involved in the pathogenesis of SLE. Mice deficient in IL$1 \beta$ developed lower levels of anti-ds-DNA antibodies (Voronov et al. 2006).

\section{Studies Performed in Humans}

A number of studies demonstrated that increased plasma concentration, as a result of $O P N$ gene polymorphism and increased protein expression, was associated with SLE susceptibility and/or clinical manifestations of the disease in humans. Study of Forton et al. (2002), including 81 Caucasoid SLE patients and Caucasoid 79 controls, showed that polymorphic $\mathrm{T}$ allele of the silent polymorphism $707 \mathrm{C}>\mathrm{T}$ (rs1126616) is associated with opportunistic infections and renal insufficiency $(p=0.0598$ and $p=0.0431$, respectively) but is protective for avascular necrosis ( $p=0.0382$ ). There was no association with cutaneous lupus, gastrointestinal lupus and specific laboratory features (Forton et al. 2002). This was the first demonstration of a phenotypic association with an $O P N$ gene polymorphism but the authors admitted that the number of patients participating in the study was too low. In a study of 394 Italian SLE patients and 479 matched controls, a total of 13 single nucleotide polymorphisms (SNPs) in $O P N$ gene were identified (six in the $5^{\prime}$ flanking region, one in intron 3, three in exons 6, 7 and 3 in the $3^{\prime}$-UTR; Table 2) (D'Alfonso et al. 2005). Five of these SNPs were newly identified. Two polymorphisms: $-156 \mathrm{G}>\mathrm{GG}$ (rs7687316) and $+1239 \mathrm{~A}>\mathrm{C}$ (rs9138) were significantly associated with SLE. The $-156 \mathrm{G}$ and $+1239 \mathrm{C}$ alleles were more frequent in SLE patients than in the control group ( $p=0.006$ and $p=0.00094$, respectively). In addition, significant association was seen between lymphadenopathy and -156 genotypes $(p=0.0011)$. Significantly increased OPN serum level was detected in healthy individuals carrying $+1239 \mathrm{C}(p=0.002)$. The authors suggested that $-156 \mathrm{G}>\mathrm{GG}$ and $-1239 \mathrm{~A}>\mathrm{C}$ polymorphisms predispose to high production of OPN and susceptibility to SLE.

These data suggest that OPN genetic variants have a key role in creating a background favoring lymphocyte accumulation and leading to the development of autoimmunity. OPN may exert its effect through its capacity to stimulate proliferation and to inhibit apoptosis of lymphocytes or 


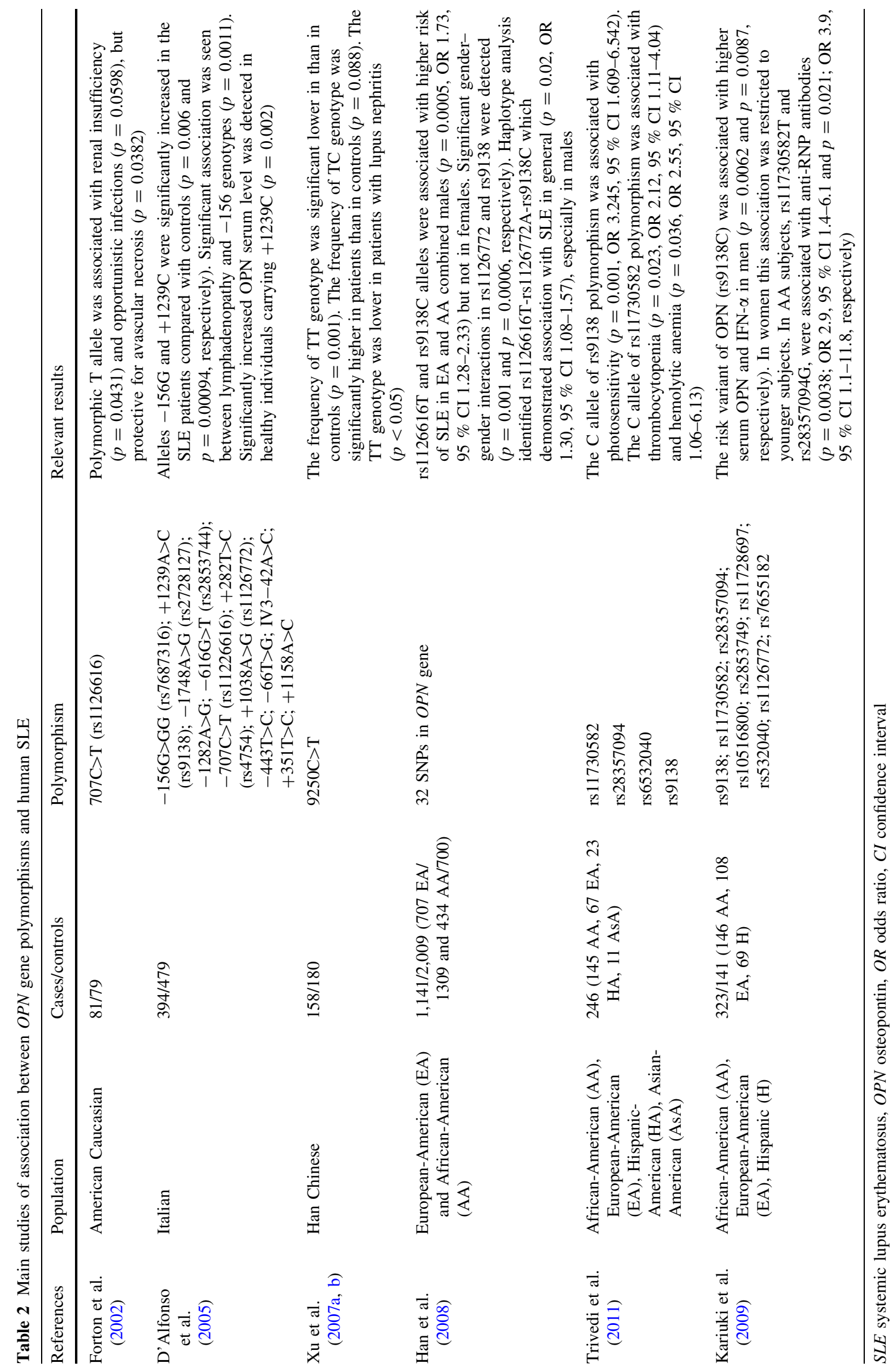


through its capacity to modulate the immune response by inducing Th1 responses and potentiating polyclonal activation of B cells.

$\mathrm{Xu}$ et al. (2007a) demonstrated that single nucleotide polymorphism at position 9259 in exon 7 of the $O P N$ gene $(O P N$ gene $9250 \mathrm{C}>\mathrm{T})$ exists in the Chinese Han ethnic population and is associated with SLE. The frequency of TT genotype was significantly lower in SLE patients $(n=158)$ than in the controls $(n=180 ; p=0.001)$. The frequency of TC genotype was significantly higher in patients compared to controls $(p=0.088)$. When the SLE patients and controls were separated into women and men, significant differences of frequencies were noted in TT genotype, TC genotype and allele in women, but not in men (Xu et al. 2007a). Moreover, this polymorphism appears to be associated with the susceptibility to lupus nephritis in this population. The TT genotype was lower in SLE patients with lupus nephritis $(p<0.05)$ (Xu et al. 2007b). In a large study of 1,141 SLE patients (707 European-American, 434 African-American) Han et al. (2008) performed the population-based case-control analyses. It was reported that minor alleles of rs1126616 and rs9138 ( $\mathrm{T}$ and C, respectively) were significantly correlated with higher risk of SLE in combined two ethnic groups of males $(p=0.0005$; OR $1.73,95 \%$ CI 1.28-2.33) but not in females (Han et al. 2008). Moreover, significant gendergender interactions in rs1126616 and rs9138 were detected ( $p=0.001$ and $p=0.0006$, respectively). Furthermore, haplotype analysis identified rs1126616T-rs1126772Ars9138C which demonstrated association with SLE in general ( $p=0.02$; OR $1.30,95 \%$ CI 1.08-1.57), especially in males. Han et al. (2008) suggested that $O P N$ gene polymorphism is associated with SLE, especially in males and it was the first description of a gender-specific human lupus genetic association. In another study, Trivedi et al. (2011) examined 246 patients diagnosed with SLE, genotyping the rs11730582, rs28357094, rs6532040 and rs9138 SNPs in the $O P N$ gene. They proved that photosensitivity in SLE patients was associated with the risk allele rs9138C $(p=0.001$; OR $3.245,95 \%$ CI 1.609-6.542). It is known that cutaneous lupus is characterized by photosensitivity, UV-mediated apoptosis of keratinocytes and an inflammatory infiltration into the skin. The accumulation of pDC (IFN- $\alpha$-producing cells) in the skin was demonstrated to be important in these conditions (Blomberg et al. 2001). In addition, the study of Trivedi et al. (2011) demonstrated that the $\mathrm{C}$ allele of rs 11730582 polymorphism is associated with thrombocytopenia $(p=0.023$; OR $2.12,95 \% \mathrm{CI}$ 1.11-4.04) and hemolytic anemia $(p=0.036$; OR 2.55, $95 \%$ CI 1.06-6.13). Previous study of Kariuki et al. (2009) revealed an association of the rs $9138 \mathrm{C}$ allele with higher levels of OPN and IFN- $\alpha$ in a small cohort of male SLE patients $(p=0.0062$ and $p=0.0087$, respectively). The mechanism by which $O P N$ gene polymorphism modulates serum IFN- $\alpha$ is unclear but murine data suggest a role of OPN in IFN- $\alpha$ production by pDC (Shinohara et al. 2006). Moreover, in African-American SLE subjects $(n=434)$, participating in the study of Kariuki et al. (2009), two SNPs: rs11730582 and rs28357094, were associated with anti-ribonucleoprotein (anti-RNP) autoantibodies $(p=0.0038$; OR 2.9, $95 \%$ CI 1.4-6.1 and $p=0.021$; OR $3.9,95 \%$ CI 1.1-11.8, respectively).

\section{Concluding Remarks}

This review has summarized the advances in understanding of the role of OPN in pathogenesis and outcome of SLE. Osteopontin, a pleiotropic protein highly expressed by various cell types such as cells of the immune system, regulates immune response. A large number of publications suggest that OPN participates in the pathogenesis of many autoimmune diseases, including SLE. It has been demonstrated that OPN expression is increased in SLE patients and is associated with some clinical manifestations and levels of activity, but with divergences in the different populations studied. Causes of these differences include probably ethnic and environmental factors (diet, medications, tobacco smoking, ultraviolet light) and still unknown factors. The association of SLE and $O P N$ gene polymorphism is still rarely reported. However, most of the results indicate that it might be a good molecular marker for the susceptibility to, and severity of SLE. Further studies should improve our understanding of the disease and will contribute to more precise diagnosis and treatment of SLE.

\section{Current Challenges and Future Research Directions}

There are reports suggesting the role of OPN and $O P N$ gene polymorphism in pathogenesis and/or clinical manifestations of SLE. Unfortunately, many of these studies do not meet the current rigorous standards for non-biased large-cohort trials. Future research should focus on selecting the best study group to investigate the role of OPN in SLE. Statistical analysis of the results should take into account many factors, including sex, age, ethnic group, diet, medications and environmental factors. Studies of $O P N$ gene polymorphism must take into account the genegene, gene-environment interactions and ethnic factors. Currently, little work has been focused on understanding the molecular mechanism whereby OPN exerts its various effects. Moreover, both randomized trials and long-term follow-up studies are needed to show the efficacy of treatment of autoimmune diseases (e.g., SLE) with antiOPN antibodies. 
Conflict of interest The author declares that have not any competing financial interests.

Open Access This article is distributed under the terms of the Creative Commons Attribution License which permits any use, distribution, and reproduction in any medium, provided the original author(s) and the source are credited.

\section{References}

Afify MF, Mohamed GB, El-Maboud MA et al (2009) Plasma concentration of osteopontin (OPN) in children with systemic lupus erythematosus: relationship with disease activity. Open Autoimmun J 1:59-63

Al-Shami R, Sørensen ES, Ek-Rylander B et al (2005) Phosphorylated osteopontin promotes migration of human choriocarcinoma cells via a p70 S6 kinase-dependent pathway. J Cell Biochem 94:1218-1233

Ashkar S, Weber GF, Panoutsakopoulou V et al (2000) Eta-1 (osteopontin): an early component of type-1 (cell-mediated) immunity. Science 287:860-864

Bengtsson AA, Sturfelt G, Truedsson L et al (2000) Activation of type I interferon system in systemic lupus erythematosus correlates with disease activity but not with antiretroviral antibodies. Lupus 9:664-671

Blomberg S, Eloranta ML, Cederblad B et al (2001) Presence of cutaneous interferon-alpha producing cells in patients with systemic lupus erythematosus. Lupus 10:484-490

Brown A (2012) Osteopontin: a key link between immunity, inflammation and the central nervous system. Transl Neurosci 3:288-293

Cantor H (1995) The role of Eta-1/osteopontin in the pathogenesis of immunological disorders. Ann N Y Acad Sci 760:143-150

Cao DX, Li ZJ, Jiang XO et al (2012) Osteopontin as potential biomarker and therapeutic target in gastric and liver cancers. World J Gastroenterol 18:3923-3930

Carecchio M, Comi C (2011) The role of osteopontin in neurodegenerative diseases. J Alzheimers Dis 25:179-185

Chiu YW, Tu HF, Wang IK et al (2010) The implication of osteopontin (OPN) expression and genetic polymorphisms of OPN promotor in oral carcinogenesis. Oral Oncol 46:302-306

Cho HJ, Cho HJ, Kim HS (2009) Osteopontin: a multifunctional protein at the crossroads of inflammation, atherosclerosis, and vascular calcification. Curr Atheroscler Rep 11:206-213

D'Alfonso S, Barizzone N, Giordano M et al (2005) Two singlenucleotide polymorphisms in the 50 and 30 ends of the osteopontin gene contribute to susceptibility to systemic lupus erythematosus. Arthritis Rheum 52:539-547

Denda S, Reichardt L, Müller U (1998) Identification of osteopontin as a novel ligand for the integrin alpha 8 beta 1 and potential role for this integrin-ligand interaction in kidney morphogenesis. Mol Biol Cell 9:1425-1435

Denhardt DT, Guo X (1993) Osteopontin: a protein with the diverse functions. FASEB J 7:1475-1482

Denhardt DT, Noda M (1998) Osteopontin expression and function: role in bone remodeling. J Cell Biochem Suppl 30:92-102

Fisher LW, Torchia DA, Fohr B et al (2001) Flexible structures of SIBLING proteins, bone sialoprotein, and osteopontin. Biochem Biophys Res Commun 280:460-465

Forton AC, Petri MA, Goldman D et al (2002) An osteopontin (SPP1) polymorphism is associated with systemic lupus erythematosus. Hum Mutat 19:459

Frenzel DF, Weiss JM (2011) Osteopontin and allergic disease: pathophysiology and implications for diagnostics and therapy. Expert Rev Clin Immunol 7:93-109
Gericke A, Qin C, Spevak L et al (2005) Importance of phosphorylation for osteopontin regulation of biomineralization. Calcif Tissue Int 77:45-54

Giacopelli F, Rosatto N, Divizia MT et al (2003) The first intron of the human osteopontin gene contains a C/EBP-beta-responsive enhancer. Gene Expr 11:95-104

Giles BM, Boackle SA (2013) Linking complement and anti-dsDNA antibodies in the pathogenesis of systemic lupus erythematosus. Immunol Res 55:10-21

Glas J, Seiderer J, Bayrle C et al (2011) The role of osteopontin (OPN/SPP1) haplotypes in the susceptibility to Crohn's disease. PLoS One 6:e29309

Gravallese EM (2003) Osteopontin: a bridge between bone and the immune system. J Clin Invest 112:147-149 (erratum in: J Clin Invest 112:627)

Green PM, Ludbrook SB, Miller DD et al (2001) Structural elements of the osteopontin SVVYGLR motif important for the interaction with alpha (4) integrins. FEBS Lett 503:75-79

Han S, Guthridge JM, Harley IT et al (2008) Osteopontin and systemic lupus erythematosus association: a probable genegender interaction. PLoS One 3:e0001757

Harris VK, Sadiq SA (2009) Disease biomarkers in multiple sclerosis: potential for use in therapeutic decision making. Mol Diagn Ther $13: 225-244$

Heilmann K, Hoffmann U, Witte E et al (2009) Osteopontin as twosided mediator of intestinal inflammation. J Cell Mol Med 13:1162-1174

Hu DD, Lin EC, Kovach NL et al (1995) A biochemical characterization of the binding of osteopontin to integrins alpha $\mathrm{v}$ beta 1 and alpha v beta 5. J Biol Chem 270:26232-26238

Iizuka J, Katagiri Y, Tada N et al (1998) Introduction of an osteopontin gene confers the increase in $\mathrm{B} 1$ cell population and the production of anti-DNA autoantibodies. Lab Invest 78:1523-1533

Ito K, Kon S, Nakayama Y et al (2009) The differential amino acid requirement within osteopontin in alpha 4 and alpha 9 integrinmediated cell binding and migration. Matrix Biol 28:11-19

Iwasaki H, Shinohara Y, Ezura Y et al (2001) Thirteen singlenucleotide polymorphisms in the human osteopontin gene identified by sequencing of the entire gene in Japanese individuals. J Hum Genet 46:544-546

Jiang Y, Yao M, Liu Q et al (2013) OPN gene polymorphisms influence the risk of knee OA and OPN levels in synovial fluid in a Chinese population. Arthritis Res Ther 15:R3

Kariuki SN, Niewold TB (2010) Genetic regulation of serum cytokines in systemic lupus erythematosus. Transl Res 155:109-117

Kariuki SN, Moore JG, Kirou KA et al (2009) Age- and genderspecific modulation of serum osteopontin and interferon-alpha by osteopontin genotype in systemic lupus erythematosus. Genes Immun 10:487-494

Katagiri Y, Mori K, Hara T et al (1995) Functional analysis of the osteopontin molecule. Ann N Y Acad Sci 760:371-374

Kazanecki CC, Uzwiak DJ, Denhardt DT (2007) Control of osteopontin signaling and function by post-translational phosphorylation and protein folding. $\mathrm{J}$ Cell Biochem 102:912-924

Koh A, da Silva AP, Bansal AK et al (2007) Role of osteopontin in neutrophil function. Immunology 122:466-475

Konno S, Kurokawa M, Uede T et al (2011) Role of osteopontin, a multifunctional protein, in allergy and asthma. Clin Exp Allergy 41:1360-1366

Kontoyiannis D, Kollias G (2000) Accelerated autoimmunity and lupus nephritis in NZB mice with an engineered heterozygous deficiency in tumor necrosis factor. Eur $\mathrm{J}$ Immunol 30:2038-2047 
Kotzin BL (1996) Systemic lupus erythematosus. Cell 85:303-306

Lampe MA, Patarca R, Iregui MV et al (1991) Polyclonal B cell activation by the Eta-1 cytokine and the development of systemic autoimmune disease. J Immunol 147:2902-2906

Li L, Yu XQ, Yin PD et al (1999) [OPN expression of peripheral blood mononuclear cells in systemic lupus erythematosus (SLE) and its clinical significance] in Chinese. Chin J Rheumatol 3:84-86

Lindop R, Arentz G, Thurgood LA et al (2012) Pathogenicity and proteomic signatures of autoantibodies to Ro and La. Immunol Cell Biol 90:304-309

Lou B, Lv J, Zheng M (2006) The relationship between osteopontin plasma concentration and disease activity in systemic lupus erythematosus. Chin J Dermatol 39:320-321

Marks SD, Tullus K (2012) Autoantibodies in systemic lupus erythematosus. Pediatr Nephrol 27:1855-1868

Mills JA (1994) Systemic lupus erythematosus. N Engl J Med 330:1871-1879

Mishima R, Takeshima F, Sawai T et al (2007) High plasma osteopontin levels in patients with inflammatory bowel disease. J Clin Gastroenterol 41:167-172

Miyazaki T, Ono M, Qu WM et al (2005) Implication of allelic polymorphism of osteopontin in the development of lupus nephritis in MRL/lpr mice. Eur J Immunol 35:1510-1520

Mochida S, Hashimoto M, Matsui A et al (2004) Genetic polymorphisms in promoter region of osteopontin gene may be a marker reflecting hepatitis activity in chronic hepatitis $\mathrm{C}$ patients. Biochem Biophys Res Commun 313:1079-1085

Murugaiyan G, Mittal A, Weiner HL (2008) Increased osteopontin expression in dendritic cells amplifies IL-17 production by $\mathrm{CD} 4+\mathrm{T}$ cells in experimental autoimmune encephalomyelitis and in multiple sclerosis. J Immunol 181:7480-7488

Oldberg A, Franzen A, Heinegard D (1986) Cloning and sequence analysis of rat bone sialoprotein (osteopontin), cDNA reveals an Arg-Gly-Asp cell binding sequence. Proc Natl Acad Sci USA 83:8819-8823

Ophascharoensuk V, Giachelli CM, Gordon K et al (1999) Obstructive uropathy in the mouse: role of osteopontin in interstitial fibrosis and apoptosis. Kidney Int 56:571-580

Patarca R, Freeman GJ, Singh RP et al (1989) Structural and functional studies of the early $\mathrm{T}$ lymphocyte activation 1 (Eta-1) gene. Definition of a novel T cell-dependent response associated with genetic resistance to bacterial infection. J Exp Med 170:145-161

Ramaiah SK, Rittling S (2008) Pathophysiological role of osteopontin in hepatic inflammation, toxicity, and cancer. Toxicol Sci 103:4-13

Rangaswami H, Bulbule A, Kundu GC (2006) Osteopontin: role in cell signaling and cancer progression. Trends Cell Biol 16:79-87

Razzouk S, Brunn JC, Qin C et al (2002) Osteopontin posttranslational modifications, possibly phosphorylation, are required for in vitro bone resorption but not osteoclast adhesion. Bone 30:40-47

Rekvig OP, Putterman C, Casu C et al (2012) Autoantibodies in lupus: culprits or passive bystanders? Autoimmun Rev 11:596-603

Rullo OJ, Woo JM, Parsa MF et al (2013) Plasma levels of osteopontin identify patients at risk for organ damage in systemic lupus erythematosus. Arthritis Res Ther 15:R18

Scatena M, Liaw L, Giachelli CM (2007) Osteopontin: a multifunctional molecule regulating chronic inflammation and vascular disease. Arterioscler Thromb Vasc Biol 27:2302-2309

Shinohara ML, Lu L, Bu J et al (2006) Osteopontin expression is essential for interferon-alpha production by plasmacytoid dendritic cells. Nat Immunol 7:498-506
Shinohara ML, Kim JH, Garcia VA et al (2008) Engagement of the type I interferon receptor on dendritic cells inhibits T helper 17 cell development: role of intracellular osteopontin. Immunity 29:68-78

Singh M, Ananthula S, Milhorn DM et al (2007) Osteopontin: a novel inflammatory mediator of cardiovascular disease. Front Biosci $12: 214-221$

Sodek J, Ganss B, McKee MD (2000) Osteopontin. Crit Rev Oral Biol Med 11:279-303

Thibault DL, Chu AD, Graham KL et al (2008) IRF9 and STAT1 are required for $\mathrm{IgG}$ autoantibody production and $\mathrm{B}$ cell expression of TLR7 in mice. J Clin Invest 118:1417-1426

Trivedi T, Franek BS, Green SL et al (2011) Osteopontin alleles are associated with clinical characteristics in systemic lupus erythematosus. J Biomed Biotechnol 2011:802581

Uede T (2011) Osteopontin, intrinsic tissue regulator of intractable inflammatory diseases. Pathol Int 61:265-280

Urtasun R, Lopategi A, George J et al (2012) Osteopontin, an oxidant stress sensitive cytokine, up-regulates collagen-I via integrin $\alpha(\mathrm{V}) \beta(3)$ engagement and PI3 K/pAkt/NFkB signaling. Hepatology 55:594-608

Voronov E, Dayan M, Zinger H et al (2006) IL-1 beta-deficient mice are resistant to induction of experimental SLE. Eur Cytokine Netw 17:109-116

Wang KX, Denhardt DT (2008) Osteopontin: role in immune regulation and stress response. Cytokine Growth Factor Rev 19:333-345

Weber GF, Cantor H (2001) Differential roles of osteopontin/Eta-1 in early and late lpr disease. Clin Exp Immunol 126:578-583

Weber GF, Ashkar S, Glimcher MJ et al (1996) Receptor-ligand interaction between CD44 and osteopontin (Eta-1). Science 271:509-512

Wong CK, Lit LC, Tam LS et al (2005) Elevation of plasma osteopontin concentration is correlated with disease activity in patients with systemic lupus erythematosus. Rheumatology 44:602-606

Wüthrich RP, Fan X, Ritthaler T et al (1998) Enhanced osteopontin expression and macrophage infiltration in MRL-Fas(lpr) mice with lupus nephritis. Autoimmunity 28:139-150

$\mathrm{Xu}$ AP, Bai J, Lü J et al (2007a) Osteopontin gene polymorphism in association with systemic lupus erythematosus in Chinese patients. Chin Med J 120:2124-2128

Xu AP, Liang YY, Lü J et al (2007b) Association of osteopontin gene polymorphism with lupus nephritis in Chinese Han population. Nan Fang Yi Ke Da Xue Xue Bao 27:1348-1351 (in Chinese)

Yap DY, Lai KN (2013) The role of cytokines in the pathogenesis of systemic lupus erythematosus-from bench to bedside. Nephrology 18:243-255

Yilmaz Y (2012) Review article: non-alcoholic fatty liver disease and osteoporosis-clinical and molecular crosstalk. Aliment Pharmacol Ther 36:345-352

Yokosaki Y, Tanaka K, Higashikawa F et al (2005) Distinct structural requirements for binding of the integrins alphavbeta6, alphavbeta3, alphavbeta5, alpha5beta1 and alpha9beta1 to osteopontin. Matrix Biol 24:418-427

Yokoyama H, Kreft B, Kelley VR (1995) Biphasic increase in circulating and renal TNF-alpha in MRL-lpr mice with differing regulatory mechanisms. Kidney Int 47:122-130

Zandman-Goddard G, Shoenfeld Y (2003) SLE and infections. Clin Rev Allergy Immunol 25:29-40 